ISSN: 1412-8241 (p); 2621-1246 (e), Volume 21. no (1) 2018

DOI: 10.22437/jiseb.v21i1

\title{
HUBUNGAN PENYULUHAN PERTANIAN DENGAN PRODUKTIVITAS KERJA PETANI SAYURAN DI KECAMATAN KUMPEH ULU KABUPATEN MUARO JAMBI
}

\author{
Ana Puja Prihatin ${ }^{1}$, Aprolita $^{2}$ dan Tri Suratno ${ }^{2}$ \\ 1) Alumni Program Studi Agribisnis Fakultas Pertanian Universitas Jambi \\ ${ }^{2)}$ Staf Pengajar Program Studi Agribisnis Fakultas Pertanian Universitas Jambi \\ Email : anapujaprihatin@gmail.com
}

\begin{abstract}
ABSTRAK
Penelitian ini bertujuan untuk mengetahui produktivitas kerja petani sayuran dan mengetahui hubungan penyuluhan pertanian dengan produktivitas kerja petani sayuran di Kecamatan Kumpeh Ulu Kabupaten Muaro Jambi. Penentuan lokasi ditentukan secara purposive dan penentuan responden dilakukan menggunakan teknik simple random sampling. Metode analisis data yang digunakan adalah analisis deskriptif menggunakan tabel distribusi frekuensi untuk mengetahui produktivitas kerja petani sayuran. Untuk mengetahui hubungan penyuluhan pertanian dengan produktivitas kerja petani sayuran digunakan analisis statistika non parametrik melalui uji Chi Square $\left(x^{2}\right)$. Hasil penelitian menunjukkan Produktivitas kerja petani sayuran dilokasi penelitian masih tergolong rendah yaitu sebesar $43 \%$. Tinggi rendahnya produktivitas kerja petani sayuran dipengaruhi oleh jumlah produksi yang dihasilkan petani dan besarnya penerimaan yang diterima oleh petani. Penerimaan yaitu produksi dikali harga. Seringkali harga yang berlaku dikalangan petani sayuran masih tergolong rendah dan berada di bawah harga pasar, harga yang rendah tentu akan mempengaruhi besar kecilnya penerimaan serta produktivitas kerja petani.Terdapat hubungan yang nyata antara penyuluhan pertanian dengan produktivitas kerja petani sayuran di kecamatan Kumpeh Ulu Kabupaten Muaro Jambi sebesar $67,83 \%$, hal ini menunjukkan bahwa semakin sering petani mendapatkan kegiatan penyuluhan pertanian maka petani akan semakin terdorong untuk meningkatkan produktivitas kerjanya.
\end{abstract}

Kata Kunci : Penyuluhan, Produktivitas Kerja, Petani

\section{ABSTRACT}

This study aims to (i) determine labor productivity vegetable farmers (ii) determine the relationship with the agricultural extension work productivity vegetable farmers in the district of Kumpeh Ulu. Determining the location by purposive and determine the respondents conducted using simple random sampling technique. The analysis method used is descriptive analysis using frequency distribution tables to determine the productivity of vegetable farmers. To determine the relationship with the agricultural extension work productivity vegetable farmers use nonparametric statistical analysis through Chi Square test $\left(x^{2}\right)$. The results showed labor productivity vegetable farmers in the location of research is still relatively low at 43\%. High and low productivity of vegetable farmers affected by the amount of production produced by farmers and the amount of revenue received by farmers. Acceptance is the production multiplied by the price. Often the prices prevailing among vegetable farmers have been still low and is below the market price, a low price will certainly affect the size of the reception as well as labor productivity. The real relationship between agricultural extension work productivity vegetable farmers in the district of Kumpeh Ulu Muaro Jambi amounting to 67.83\%, this shows that the more often farmers obtain agricultural extension activities, the farmers will be encouraged to improve their productivity. 
JURNAL ILMIAH SOSIO-EKONOMIKA BISNIS

ISSN: $1412-8241$ (p); 2621-1246 (e), Volume 21. no (1) 2018

DOI: $10.22437 /$ jiseb.v21i1

Keywords: Extension, Labor Productivity, Farmers

\section{PENDAHULUAN}

Provinsi Jambi memiliki potensi yang sangat mendukung untuk melakukan kegiatan usahatani sayuran. Provinsi jambi terbagi kedalam dua kota dan sembilan Kabupaten termasuk di dalamnya Kabupaten Muaro Jambi. Berdasarkan data produksi sayur dan buah Kabupaten Muaro Jambi tahun 2015. Terdapat 10 jenis tanaman sayur yang ditanam di Kabupaten Muaro Jambi. Tanaman sayur tersebut meliputi : sawi, cabai besar, cabai rawit, tomat, terung, buncis, ketimun, kangkung, bayam, dan kacang panjang. Kecamatan Kumpeh Ulu adalah salah satu Kecamatan di Kabupaten Muaro Jambi yang memiliki potensi di bidang pertanian pangan dan hortikultura. Kedua sektor ini memiliki peran yang cukup besar dalam menyerap tenaga kerja dan meningkatkan perekonomian masyarakat. Kecamatan Kumpeh Ulu juga dikenal sebagai daerah penghasil sayur dan buah-buahan utama, dan sebagian besar penduduk di Kumpeh Ulu bermata pencarian sebagai petani, khususnya tanaman palawija dan hortikultura, hal ini didukung kondisi lahan yang sebagian terdiri dari dataran rendah atau lahan basah sehingga sangat cocok untuk budidaya tanaman buah-buahan dan sayuran.

Pada tahun 2015, di Kecamatan Kumpeh Ulu, tanaman hortikultura memiliki areal panen yang cukup luas dibandingkan dengan tanaman pangan. Kecamatan Kumpeh Ulu memiliki 18 Desa, dari 18 Desa terdapat 13 Desa yang menanam tanaman sayuran dan telah tergabung dalam kelompok tani sayur. 13 desa yang mengusahakan usaha tani sayuran di Kecamatan Kumpeh Ulu Kabupaten Muaro Jambi. Desa Lopak Alai adalah desa dengan produksi tertinggi sebesar 1.180 kwintal, selanjutnya yaitu desa dengan produksi rata-rata yaitu Desa Pudak dengan produksi sebesar 784 kwintal dan desa dengan Produksi terendah yaitu Desa Kota Karang dengan produksi sebesar 472 kwintal. Kenaikan produksi dan produktivitas ini hanya dimungkinkan oleh adanya peningkatan efesiensi (waktu-bahan-tenaga) dan sistem kerja, teknik produksi dan adanya peningkatan keterampilan dari tenaga kerjanya. Peningkatan keterampilan tenaga kerja (petani) salah satunya dapat diperoleh dari adanya seorang penyuluh pertanian, hal ini sejalan dengan pengertian penyuluhan pertanian. Penyuluhan pertanian adalah proses perubahan perilaku (pengetahuan, sikap, keterampilan) dikalangan masyarakat petani, agar mereka tahu, mau dan mampu melaksanakan perubahan usahataninya demi peningkatan produksi, pendapatan dan perbaikan kesejahteraan keluarga yang ingin dicapai melalui pembangunan pertanian.

Dengan melihat dari adanya peningkatan produktivitas yang hanya dapat dilakukan oleh sumber daya manusia yang memiliki peningkatan kerja dan keterampilan dalam mengusahakan usahataninya, serta peningkatan keterampilan kerja seorang petani salah satunya bisa didapatkan dari adanya penyuluh pertanian, selain itu usahatani sayur memiliki prospek cerah bagi petani di Kecamatan Kumpeh Ulu, jika diusahakan secara intensif. Komoditi ini juga cukup laris dipasaran dan memiliki nilai ekonomis yang cukup tinggi dan juga perputaran modal yang cepat, hal ini erat kaitannya dengan umur tanaman untuk produksi yang singkat dan adanya permintaan pasar yang tidak pernah berhenti karena setiap hari orang membutuhkan sayuran untuk dikonsumsi, Berdasarkan uraian latar belakang, maka penelitian ini bertujuan untuk: (i) mengetahui produktivitas kerja petani sayuran (ii) mengetahui hubungan penyuluhan pertanian dengan produktivitas kerja petani sayuran di Kecamatan Kumpeh Ulu Kabupaten Muaro Jambi. 


\section{METODE PENELITIAN}

Penelitian ini dilaksanakan di Desa Pudak, Desa Lopak Alai dan Desa Kota Karang Kecamatan Kumpeh Ulu Kabupaten Muaro Jambi ditentukan secara purposive dengan pertimbangan bahwa di Desa Pudak merupakaan desa dengan produksi sayur tertinggi, Desa Lopak Alai dengan desa produksi sayur sedang dan Desa Kota Karang dengan produksi sayur terendah. Penelitian ini dilaksanakan dari tanggal 8 Agustus sampai 8 September 2016. Responden dalam penelitian ini adalah petani yang tergabung dalam kelompok tani dan mengusahakan usaha tani sayuran yang dipilih menggunkan teknik simple random sampling.

Terdapat dua variabel di dalam penelitian ini, variabel bebas yaitu penyuluh pertanian dan variabel terikat produktivitas kerja petani sayuran. Indikator yang diukur dari penyuluhan pertanian yaitu kegiatan penyuluhan pertanian, sasaran penyuluhan pertanian, metode penyuluhan pertanian, media penyuluhan pertanian, materi penyuluhan pertanian, waktu penyuluhan pertanian dan tempat penyuluhan pertanian.

Kriteria penyuluhan pertanian:

a. Penyuluhan Pertanian dikatakan tinggi jika besar dari nilai rata-rata yaitu diatas 75 .

b. Penyuluhan Pertanian dikatakan rendah jika kecil dari nilai rata-rata yaitu dibawah 75.

Selanjutnya untuk produktivitas Kerja indikator yang diukur yaitu penerimaan dibagi dengan jumlah HOK. Penerimaan yaitu produksi dikali dengan harga, sedangakan HOK yaitu jumlah orang atau tenaga kerja dikali jumlah hari kerja dikali jam kerja dibagi 7 (1 Hari = 7 Jam Kerja), produktivitas kerja petani dikategorikan dalam :

a. Tinggi $>$ Rata-Rata

b. Rendah < Rata-Rata

Metode analisis yang digunakan dalam penelitian ini adalah analisis secara deskriptif menggunakan tabel distribusi frekuensi untuk mengetahui produktivitas kerja petani sayuran dan untuk mengetahui hubungan dengan produktivitas digunakan analisis statistika non parametrik melalui Uji Chi Square $\left(x^{2}\right)$. Menurut Sugiyono (2015), analisis statistika non parametrik melalui Uji Chi Square $\left(x^{2}\right)$ digunakan untuk menguji hipotesis komparatif dua sampel bila datanya berbentuk nominal dan sampelnya besar. Cara perhitungan dapat menggunakan tabel kontigensi $2 \times 2$, (dua baris $x$ dua kolom) dengan derajat bebas $(\mathrm{db})=1$ dengan rumus sebagai berikut :

$$
x^{2}=\frac{N([A D-B C]}{(A+B)(C+D)(A+C)(B+D)}
$$

Tabel 1. Model Analisis Uji Chi-Square dengan Kontingensi (c) 2×2

\begin{tabular}{cccc}
\hline $\begin{array}{c}\text { Penyuluhan } \\
\text { pertanian }\end{array}$ & Tinggi & Rendah & Jumlah \\
\hline Tinggi & A & B & A+B \\
Rendah & C & D & C+D \\
\hline Jumlah & A+C & B+D & N \\
\hline
\end{tabular}


ISSN: 1412-8241 (p); 2621-1246 (e), Volume 21. no (1) 2018

DOI: $10.22437 /$ jiseb.v21i1

Selanjutnya mencari nilai c (Koefisien Kontigensi), dengan rumus :

$\mathrm{c}=\sqrt{\frac{x^{2}}{N+x^{2}}}$

Dimana :

$\mathrm{N}=$ Jumlah Sampel

$x^{2}=$ Nilai Chi Square

$c=$ Koefisien Kontigensi

Nilai Koefisien kontigensi Lemah apabila berada diantara $0-0,353$

Nilai Koefisien kontigensi Kuat apabila berada diantara 0,353-0,707

Formulasi :

$\mathrm{r}=\frac{C \text { hit }}{C \max } \quad \mathrm{c} \max =\sqrt{\frac{m-1}{m}}=\sqrt{\frac{1}{2}}=0,707$

$$
r=\frac{\sqrt{\frac{x^{2}}{x^{2}+\mathrm{N}}}}{\frac{\sqrt{m-1}}{m}}
$$

Keterangan :

$r=$ koefisien keeratan hubungan

$x^{2}=$ Nilai uji Chi-Square

$\mathrm{N}=$ Jumlah Sampel

$\mathrm{M}=$ Jumlah kolom.

\section{HASIL DAN PEMBAHASAN}

\section{Produktivitas Kerja Petani Responden}

Peningkatan produktivitas kerja hanya mungkin dilakukan manusia, oleh karena itu tenaga kerja merupakan faktor penting untuk mengukur produktivitas. Produktivitas kerja yang dimaksudkan dalam dalam penelitian ini adalah perbandingan antara penerimaan dengan jumlah curahan tenaga kerja yang dikerahkan dalam 1 (satu) musim tanam atau penerimaan per hari orang kerja (HOK). Hasil penelitian menunjukan bahwa produktivitas kerja petani responden terendah Rp.29.732 /HOK dan tertinggi Rp.251.540/HOK dengan rata-rata Rp.96.033 /HOK.

Tabel 2. Distribusi Responden Berdasarkan Produktivitas Kerja Petani Sayuran dalam Satu Musim Tanam di Derah Penelitian Tahun 2016

\begin{tabular}{ccccc}
\hline No & Kelas Skor & Kategori Skor & Frekuensi & $\begin{array}{c}\text { Presentas } \\
\text { e (\%) }\end{array}$ \\
\hline 1 & Tinggi (>Rata-rata) & $\mathrm{T}$ & 19 & 43 \\
2 & Rendah (<Rata -rata) & $\mathrm{R}$ & 25 & 57 \\
\hline \multicolumn{2}{c}{ Jumlah } & & $\mathbf{4 4}$ & $\mathbf{1 0 0}$ \\
\hline
\end{tabular}

Tabel 2 menunjukkan bahwa sebanyak 19 orang (43\%) petani responden memiliki produktivitas kerja yang tinggi dan sebanyak 25 orang (57\%) petani responden memiliki produktivitas kerja yang rendah. Dengan demikian bisa disimpulkan bahwa curahan tenaga kerja yang dikerahkan petani sayuran dalam satu musim tanam didaerah penelitian relatif rendah.

\section{Penyuluhan Pertanian}


Dalam kegiatan penyuluhan pertanian terdapat delapan unsur yang mempengaruhi penyuluhan pertanian yaitu penyuluh pertanian, sasaran penyuluhan, metoda penyuluhan, media penyuluhan, materi penyuluhan, waktu penyuluhan, tempat penyuluhan. Penyuluh pertanian adalah seseorang yang bertugas untuk menyampaikan materi atau informasi pertanian yang disampaikan oleh penyuluh di antaranya adalah materi tentang pola tanam dan pergiliran varietas, pengendalian hama, dan pupuk berimbang. Hasil penelitian memperlihatkan bahwa skor rata-rata yang dicapai memalui kegiatan penyuluhan pertanian berkisar 74 dengan skor tertinggi 85 dan skor terendah 61. Untuk lebih jelasnya mengenai distribusi frekuensi dan presentase petani responden dari adanya penyuluhan pertanian di daerah penelitian dapat dilihat pada tabel 3.

Tabel 3. Distribusi Responden Berdasarkan Penyuluhan Pertanian di Derah Penelitian Tahun 2016

\begin{tabular}{ccccc}
\hline No & Kelas Skor & Kategori Skor & Frekuensi & $\begin{array}{c}\text { Presentase } \\
\text { (\%) }\end{array}$ \\
\hline 1 & Tinggi (>Rata-rata) & $\mathrm{T}$ & 23 & 52 \\
2 & Rendah (<Rata-Rata) & $\mathrm{R}$ & 21 & 48 \\
\hline & Jumlah & & $\mathbf{4 4}$ & $\mathbf{1 0 0}$ \\
\hline
\end{tabular}

Tabel 3 menunjukkan bahwa frekuensi dan presentase petani responden tertinggi sebanyak 23 orang atau $52 \%$ dan terendah berjumlah 21 orang atau $48 \%$. Dengan demikian, hal ini menunjukkan bahwa 23 responden setuju dan menganggap penyuluh telah mampu untuk menyampaikan penyuluhan pertanian di daerah penelitian, yang didalamnya terdapat kedelapan unsur-unsur penyuluhan pertanian (penyuluh pertanian, sasaran penyuluhan, metoda penyuluhan, media penyuluhan, materi penyuluhan, waktu penyuluhan, tempat penyuluhan).

\section{Hubungan Penyuluhan pertanian dengan produktivitas kerja petani sayuran}

Penyuluhan pertanian memiliki delapan unsur didalam kegiatan penyuluhan pertanian diantaranya yaitu adanya seorang penyuluh pertanian, sasaran penyuluhan, metoda penyuluhan, media penyuluhan, materi penyuluhan, waktu penyuluhan, dan tempat penyuluhan. Kegiatan penyuluhan pertanian sangat menentukan perubahan perilaku petani dalam meningkatkan produktivitas kerjanya, oleh sebab itu kegiatan penyuluhan pertanian juga perlu ditingkatkan.

Berdasarkan hasil penelitian terdapat indikasi hubungan antara peran penyuluhan pertanian dengan produktivitas kerja petani sayuran didaerah penelitian seperti tertera pada tabel 4 .

Tabel 4. Kotigensi Hubungan Penyuluhan Pertanian dengan Produktivitas Kerja Petani Sayuran di Daerah Penelitian Tahun 2016

\begin{tabular}{|c|c|c|c|c|}
\hline \multirow{2}{*}{ No } & \multirow{2}{*}{ Penyuluhan Pertanian } & \multicolumn{2}{|c|}{ Produktivitas Kerja } & \multirow{2}{*}{ Jumlar } \\
\hline & & Rendah(< Rata-Rata) & Tinggi (>Rata-Rata) & \\
\hline 1 & Rendah (<Rata-Rata) & 18 & 3 & 21 \\
\hline 2 & Tinggi (> Rata-Rata) & 7 & 16 & 23 \\
\hline & Jumlah & 25 & 19 & 44 \\
\hline
\end{tabular}


Tabel 4 memperlihatkan bahwa dari 21 orang petani responden yang menyatakan kegiatan penyuluhan pertanian rendah, maka terdapat 18 orang petani responden yang memiliki produktivitas kerja yang rendah dan 3 petani yang memiliki produktivitas kerja yang tinggi. Selanjutnya dari 23 orang petani responden yang menyatakan kegiatan penyuluhan pertanian tinggi, maka terdapat 7 orang petani yang menyatakan produktivitas kerja rendah dan 16 orang petani responden yang memiliki produktivitas kerja tinggi. Dengan demikian dapat disimpulkan bahwa terdapat kecenderungan hubungan antara kegiatan penyuluhan yang dilakukan dengan produktivitas kerja petani sayuran.

Berdasarkan uji statistik (uji chi-square) didapatkan nilai $x^{2}$ hitung adalah 13,67 dan nilai $x^{2}$ tabel adalah 3,84 (lampiran 18), sehingga keputusan adalah tolak $H_{0}$ dan terima $\mathrm{H}_{1}$ artinya terdapat hubungan yang nyata antara penyuluh pertanian dengan produktivitas kerja petani sayur di kecamatan Kumpeh Ulu Kabupaten Muaro Jambi.

Nilai $C_{\text {hit }}$ yang didapat adalah 0,4795 dan nilai $C_{\max }$ adalah 0,707 (lampiran 18) artinya derajat kencenderungan meningkatnya produktivitas tenaga kerja petani sayur akibat mengikuti penyuluhan pertanian adalah sebesar $47,95 \%$, dan sebaliknya derajat kecenderungan rendahnya produktivitas tenaga kerja petani sebagai akibat tidak mengikuti penyuluhan pertanian adalah sebesar $47,95 \%$.

Nilai keeratan hubungan $(r)$ adalah sebesar 0,6783 artinya terdapat derajat hubungan antara mengikuti penyuluhan pertanian dengan produktivitas tenaga kerja petani sayur sebesar $67,83 \%$. Nilai $t_{\text {hit }}$ sebesar 5,98 dan $t_{\text {tab }}(\alpha 2=5 \% d b=44)=3,841$ maka tolak Ho, artinya terdapat derajat hubungan yang nyata antara penyuluhan pertanian dengan produktivitas tenaga kerja petani sayur pada taraf kepercayaan 95\%. Dari hasil penelitian dapat disimpulkan bahwa penyuluhan pertanian yang dilakukan PPL berpengaruh terhadap produktivitas kerja petani sayuran, Semakin sering petani mendapatkan kegiatan penyuluhan pertanian maka petani akan semakin terdorong untuk meningkatkan produktivitas kerjanya. Hal ini sejalan dengan penelitian yang dilakukan oleh Irnanda (2015) yang menyatakan bahwa terdapat hubungan yang nyata antara peran penyuluh pertanian lapangan dengan produktivitas kerja petani padi sawah di Desa Sungai Duren Kecamatan Jambi Luar Kota Kabupaten Muaro Jambi.

\section{KESIMPULAN}

Berdasarkan hasil penelitian menunjukkan bahwa produktivitas kerja petani sayuran dilokasi penelitian masih tergolong rendah yaitu sebesar $43 \%$. Tinggi rendahnya produktivitas kerja petani sayuran dipengaruhi oleh jumlah produksi yang dihasilkan petani dan besarnya penerimaan yang diterima oleh petani. Penerimaan yaitu produksi dikali harga. Seringkali harga yang berlaku di kalangan petani sayuran masih tergolong rendah dan berada dibawah harga pasar, harga yang rendah tentu akan mempengaruhi besar kecilnya penerimaan serta produktivitas kerja petani. Terdapat hubungan yang nyata antara penyuluhan pertanian dengan produktivitas kerja petani sayur di kecamatan Kumpeh Ulu Kabupaten Muaro Jambi sebesar 67,83\%, hal ini menunjukkan bahwa semakin sering petani mendapatkan kegiatan penyuluhan pertanian, maka petani akan semakin terdorong untuk meningkatkan produktivitas kerjanya, dan terdapat delapan unsur yang mempengaruhi kegiatan penyuluhan pertanian tersebut yaitu penyuluh pertanian, sasaran penyuluhan, metoda penyuluhan, media penyuluhan, materi penyuluhan, waktu penyuluhan, dan tempat penyuluhan. 
JURNAL ILMIAH SOSIO-EKONOMIKA BISNIS

ISSN: 1412-8241 (p); 2621-1246 (e), Volume 21. no (1) 2018

DOI: $10.22437 /$ jiseb.v21i1

\section{UCAPAN TERIMA KASIH}

Pada kesempatan ini penulis menyampaikan ucapan terima kasih kepada Penyuluh Pertanian di Kecamatan Kumpeh Ulu, Ketua Kelompok Tani sayuran yang telah banyak membantu dalam proses penelitian dan kepada Dosen Pembimbing yang telah memberikan bimbingan sehingga proses penelitian ini dapat terselesaikan dengan baik. Selain itu ucapan terima kasih juga diucapkan untuk semua pihak yang telah membantu dalam penelitian ini.

\section{DAFTAR PUSTAKA}

Balai Penyuluhan Pertanian Kecamatan Kumpeh Ulu Kabupaten Muaro Jambi. 2014. Data kelompok tani sayuran. Kecamatan Kumpeh Ulu.

BPS Daerah Kecamatan Kumpeh Ulu. Statistik Daerah Kecamatan Kumpeh Ulu 2015. Kecamatan Kumpeh Ulu.

BPS Kabupaten Muaro Jambi. Badan Pusat Statistik Kabupaten Muaro Jambi Tahun 2015. Kabupaten Muaro Jambi.

BPS Kecamatan Kumpeh Ulu. Kumpeh ulu Dalam Angka 2015. Kecamatan Kumpeh ulu.

BPS Provinsi Jambi. 2015. Jambi dalam angka tahun 2015. Provinsi Jambi.

Hernanto, Fadoli. 1995. Ilmu Usaha Tani. Penebar Swadaya. Jakarta.

Soekartawi. 1988. Prinsip Dasar Komunikasi Pertanian. Jakarta. UI. Press.

Sugiyono. 2015. Statistika Nonparametris untuk Penelitian. Alfabeta. Bandung.

Suratiah, Ken. 2006. Ilmu Usahatani. Penebar Swadaya. Jakarta. 